\title{
Depression Diagnosis Application Using Beck Depression Inventory Method with Visual Novel Game
}

\section{Aplikasi Diagnosa Depresi dengan Metode Beck Depression Inventory dengan Pendekatan Game Visual Novel}

\author{
Moh Rizal Ihsanuddin, Cindy Taurusta \\ \{171080200215@umsida.ac.id, cindytaurusta@umsida.ac.id \}
}

Program Studi Teknik Informatika, Fakultas Sains dan Teknologi, Universitas Muhammadiyah Sidoarjo

\begin{abstract}
Disturbance of feelings with sadness that continues in the long term is an explanation of depression, which can interfere with the social life of the person who experiences it. As many as 86.94 (27\%) in 322 billion individuals in the Southeast Asia region, making it the area with the highest Depression Rate. Because of this, it is necessary to have a Depression Diagnosis Application with the beck depression inventory method with a Visual Novel game approach to give a general idea of whether the person has depression or not. The purpose of this study is to provide another alternative for users to find out whether they have depression or not with visual novel game media. This research method uses the Beck Depression Inventory where users are given 21 questions that must be answered to determine the level of depression they have. The test results on this game succeeded in detecting a person's level of depression which was proven by testing on 5 people with the results that $60 \%$ did not experience depression, 20\% experienced mood changes and 20\% experienced moderate depression. The result of this research is to produce a visual novel game with the application of depression diagnosis in it. This study is intended for people aged 15 years and over who feel they have symptoms of depression to find out their current condition.
\end{abstract}

Keywords - Analysis; Beck Depression Inventory; Game; Visual Novel

\begin{abstract}
Abstrak - Gangguan perasaan dengan rasa sedih yang berkelanjutan dalam jangka waktu yang panjang adalah penjelasan dari Depresi, Dimana bisa mengganggu kehidupan sosial dari orang yang mengalaminya. Sebesar 86,94 (27\%) pada 322 miliar individu di daerah Asia Tenggara menjadikannya sebagai daerah dengan Tingkat Depresi tertinggi. Karena hal tersebut perlu adanya Aplikasi Diagnosa Depresi dengan metode beck depression inventory dengan pendekatan game Visual Novel untuk memberikan gambaran umum orang tersebut apakah memiliki depresi atau tidak. Tujuan dari penelitian ini untuk memberikan alternatif lain pada pengguna untuk mengetahui apakah memiliki depresi atau tidak dengan media game visual novel. Metode Penelitian ini menggunakan Beck Depression Inventory dimana pengguna diberi 21 pertanyaan yang harus dijawab untuk mengetahui tingkat depresi yang dimilikinya. Hasil uji coba pada Game ini berhasil mendeteksi tingkat depresi seseorang dimana dibuktikan dengan pengujian terhadap 5 orang dengan hasil yaitu 60\% tidak mengalami depresi, 20\% mengalami perubahan mood dan $20 \%$ mengalami depresi Sedang. Hasil penelitian ini adalah menghasilkan nya game visual novel dengan penerapan diagnosa depresi didalamnya. Penelitian ini ditujukan untuk masyarakat dengan umur 15 tahun keatas yang merasa memiliki gejala depresi untuk mengetahui kondisi nya saat ini.
\end{abstract}

Kata kunci - Analisa; Beck Depression Inventory; Game; Visual Novel

\section{PENDAHULUAN}

Gangguan perasaan dengan rasa sedih yang berkelanjutan dalam jangka waktu yang panjang adalah penjelasan dari Depresi, Dimana bisa mengganggu kehidupan sosial dari orang yang mengalaminya [1]. Berdasarkan Hasil RISKESDAS 2018, menunjukkan gangguan depresi mulai dari usia remaja (15-24 tahun), dengan Pola Prevalensi 6,2\%. Pola Prevalensi depresi semakin meningkat dengan bertambahnya usia, dimana prevalensi tertinggi ada pada umur 75 tahun keatas dengan prevalensi 8,9\%, 65-74 tahun 8,0\% dan 55-64 tahun 6,5\% [2]. Analisa depresi menggunakan Visual Novel merupakan pendekatan analisa depresi yang berbeda dimana menggunakan game untuk mengetahui gambaran umum dari pengguna game tersebut.

Depresi

Depresi adalah kondisi emosional yang ditandai dengan rasa bersalah dan tidak berarti, susah tidur, Hilangnya selera makan, hilangnya hasrat seksual, kesedihan yang teramat sangat, dan hilang nya minat serta kesenangan pada aktivitas yang biasa dilakukan. Depresi sering kali berhubungan dengan berbagai masalah psikologis lain, seperti serangan panik, penyalahgunaan zat, disfungsi seksual, dan gangguan kepribadian. [3]. 


\section{Beck depression inventory}

BDI adalah skala depresi yang dikembangkan oleh Aaron T Beck pada tahun 1960-an. Skala ini didasarkan pada teori kognisi dan depresi Beck. BDI tidak hanya menangkap perubahan emosi, tetapi juga perubahan motivasi, fungsi fisik, dan karakteristik kognitif pasien depresi.

\section{Renpy}

Renpy adalah mesin pembuat visual novel. Yang digunakan untuk merancang kata, gambar dan suara sehingga dapat menceritakan kisah inspiratif yang dapat dijalankan pada perangkat computer dan perangkat seluler. Renpy menggunakan script yang mudah dipahami sehingga memungkinkan siapa saja untuk membuat visual novel secara efisien [4].

\section{Visual novel}

Visual Novel adalah game yang dapat dimainkan di komputer, dan ada juga yang pendistribusiannya melalui konsol game [5]. Visual Novel juga disebut dengan game fiksi interaktif berupa cerita novel dengan gambar statis yang dilengkapi kolom dialog untuk menceritakan dan menyampaikan dialog antar karakter.

\section{Python}

Bahasa pemrograman dinamis untuk pengembangan aplikasi merupakan penjelasan dari python. Fitur pada python dilengkapi skrip meskipun pada praktiknya penggunaan bahasa ini lebih luas mencakup pada konteks pemanfaatan dimana umumnya tidak dilakukan dengan menggunakan bahasa skrip [6].

Use case

Use case atau diagram use case merupakan pemodelan perilaku sistem informasi yang akan dibuat [7].

\section{Photoshop}

Perangkat lunak yang digunakan mendesain gambar atau biasa disebut photo design [8]. Adobe Photoshop merupakan perangkat lunak dari adobe system yang khusus untuk pemberian efek dan pengeditan gambar [9].

\section{Interaksi manusia dan komputer}

Interaksi manusia komputer merupakan bidang multidisiplin penting untuk merancang produk interaktif. Keahlian di bidang yang berbeda saling membutuhkan untuk bersama-sama mengembangkan produk interaktif yang bermanfaat [10].

\section{User interface}

User Interface merupakan cara pengguna dan program untuk berinteraksi. [11]

\section{METODE}

\section{A. Teknik pengumpulan data}

Metode yang digunakan dalam penelitian ini adalah Metode Studi Pustaka yaitu metode yang digunakan untuk mengumpulkan segala data dan informasi yang relevan yang berkaitan dengan topik penelitian. Informasi serta data yang diperoleh berasal dari buku dan jurnal tentang depresi termasuk data Riskesda 2019 tentang data situsasi kesehatan jiwa di Indonesia.

\section{B. Flowchart}

Game Visual Novel ini dibuat melalui tahapan rancangan sebagai berikut : 


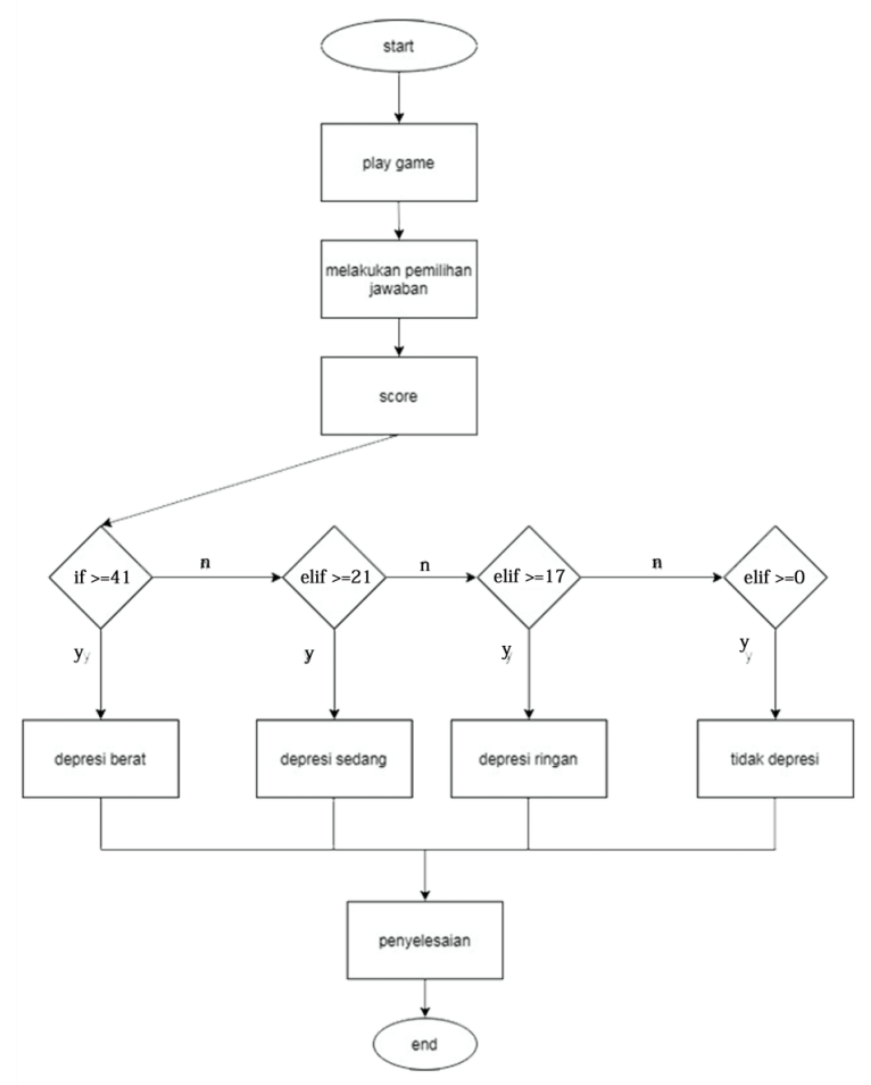

Gambar 1. Flowchart Game

Pada Flowchart ditunjukkan cara kerja dari game analisa depresi dengan visual novel ini dengan urutan seperti dibawah ini:

1. Pengguna diharuskan untuk memulai game terlebih dahulu.

2. Terdapat pilihan yang harus dipilih user untuk melanjutkan cerita dimana pilihan tersebut berisi.

3. Skor dari pilihan user akan diakumulasikan untuk mendapatkan kesimpulan tentang tingkat depresi yang dimiliki oleh user pengguna.

4. Setelah selesai melakukan penyelesaian maka game akan selesai dan kembali ke menu utama.

\section{Tampilan interface}

Rancangan interface adalah penggambaran tampilan antar muka yang akan diterapkan game Visual Novel ini. Seluruh rancangan interface berupa tampilan gameplay, save/load, pilihan dan dialog.

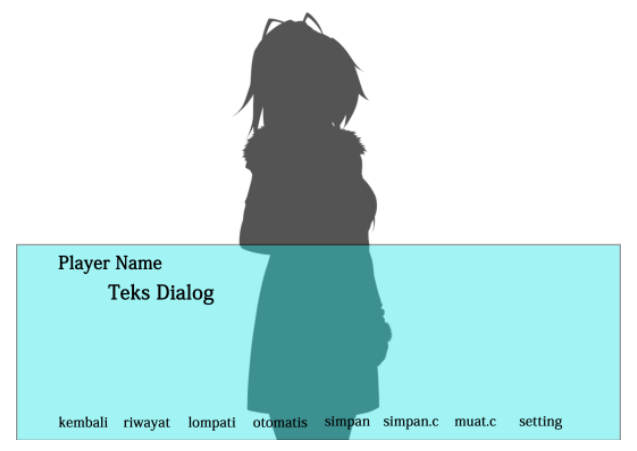

Gambar 2. Tampilan dialog

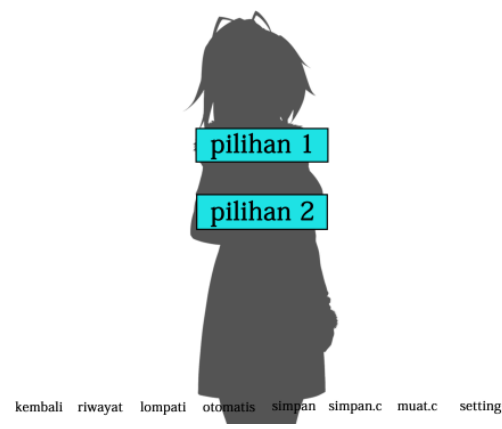

Gambar 3. Tampilan pilihan 
Procedia of Engineering and Life Science Vol. 2. No. 1 October 2021

Seminar Nasional \& Call Paper Fakultas Sains dan Teknologi (SENASAINS 3rd)

Universitas Muhammadiyah Sidoarjo

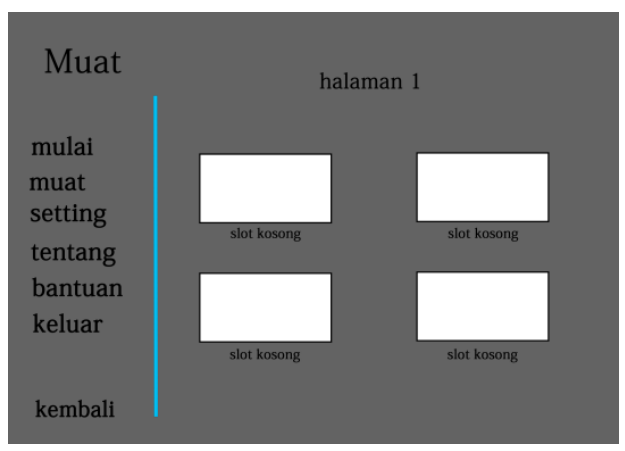

Gambar 4. Tampilan save/ load

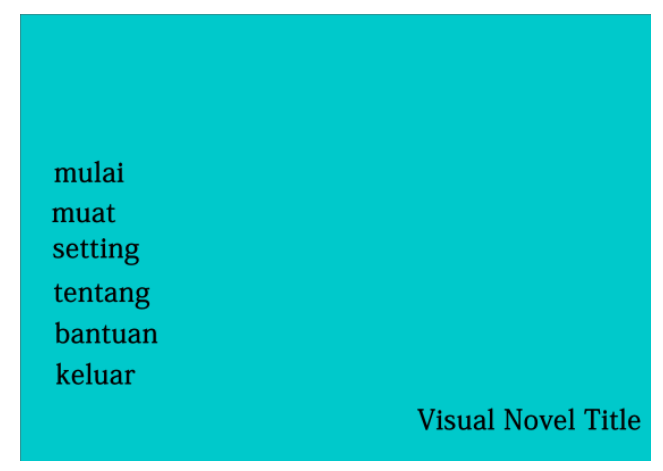

Gambar 5. Tampilan Menu Utama

Penjelasan dari interface diatas adalah sebagai berikut :

Gambar 2: tampilan dari dialog dimana disana akan ada tampilan dari percakapan yang terjadi didalam game.

Gambar 3: Tampilan pilihan berisi jawaban yang diberikan oleh pengguna ke sistem untuk melanjutkan cerita. Gambar 4: Tampilan save/load digunakan untuk menyimpan dan melanjutkan game yang dimainkan.

Gambar 5: Tampilan Menu Utama ini berisi tampilan awal pada game.

\section{HASIL DAN PEMBAHASAN}

Berikut ini merupakan hasil dari aplikasi diagnosa depresi dengan metode beck depression inventory dengan pendekatan game visual novel. Tampilan hasil game visual novel ini sebagai berikut :

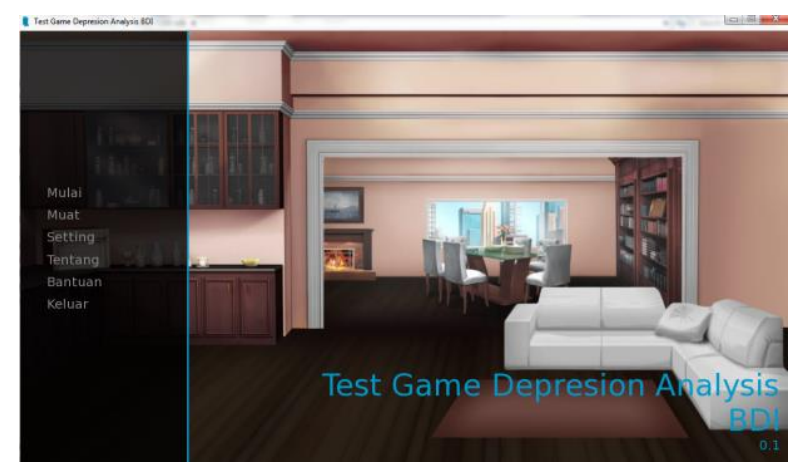

Gambar 6. Tampilan Utama

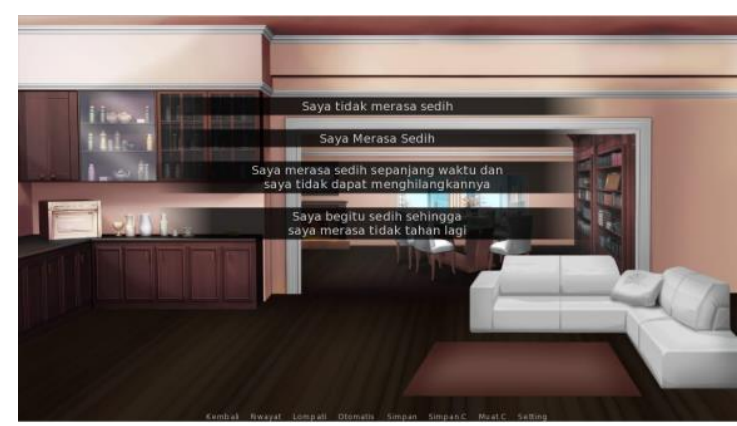

Gambar 8. Tampilan Pilihan

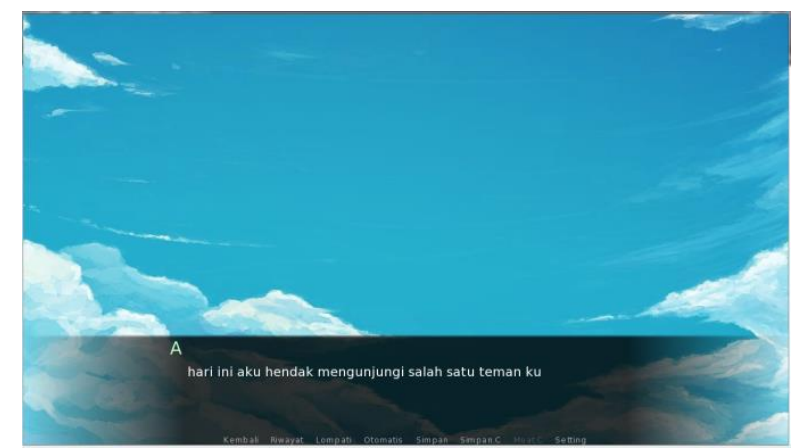

Gambar 7. Tampilan Dialog

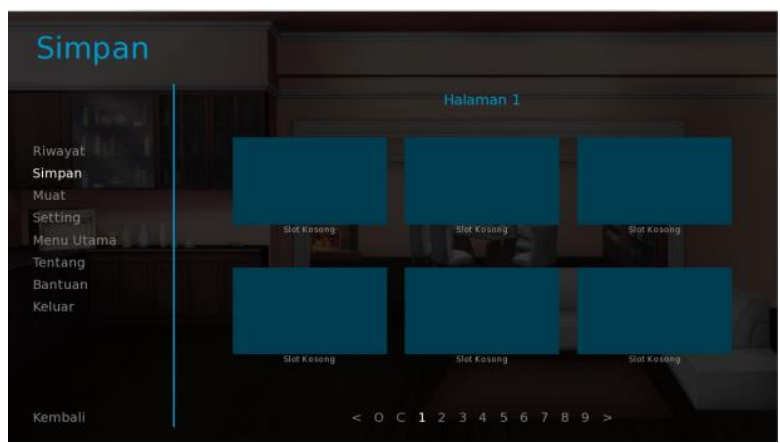

Gambar 9. Tampilan save/load 
Gambar 6: Tampilan Menu Utama ini berisi tampilan awal pada game.

Gambar 7: tampilan dari dialog dimana disana akan ada tampilan dari percakapan yang terjadi didalam game.

Gambar 8: Tampilan pilihan berisi jawaban yang diberikan oleh pengguna ke sistem untuk melanjutkan cerita.

Pada tampilan tersebut terdapat pertanyaan dari metode beck depression inventory yang harus dijawab oleh pengguna.

Gambar 9: Tampilan Save/load untuk menyimpan dan melanjutkan permainan yang sudah disimpan.

Pengujian sistem (testing)

Dalam pengujian Game Visual Novel ini tombol yang ada dalam game dicheck apakah sudah berjalan sesuai atau belum, rinciannya adalah sebagai berikut :

Tabel 1. Hasil Pengujian Sistem

\begin{tabular}{llc}
\hline \multicolumn{1}{c}{ Yang Diuji } & \multicolumn{1}{c}{ Keterangan } & Hasil \\
\hline Tombol mulai & Ketika di klik game dimulai & OK \\
\hline Tombol Muat & $\begin{array}{l}\text { Ketika di klik melanjutkan } \\
\text { game yang telah disimpan }\end{array}$ & OK \\
\hline Tombol Setting & $\begin{array}{l}\text { Ketika di klik menampilkan } \\
\text { pengaturan dari game }\end{array}$ & OK \\
\hline Tombol Tentang & $\begin{array}{l}\text { Ketika di Klik menampilkan } \\
\text { informasi dari game }\end{array}$ & OK \\
\hline Tombol Bantuan & $\begin{array}{l}\text { Ketika di Klik menampilkan } \\
\text { button yang digunakan } \\
\text { dalam memainkan game }\end{array}$ & OK \\
\hline Tombol Keluar & $\begin{array}{l}\text { Ketika di Klik maka akan } \\
\text { keluar dari game }\end{array}$ & OK \\
\hline Tombol Riwayat & $\begin{array}{l}\text { Ketika di Klik menampilkan } \\
\text { riwayat percakapan yang } \\
\text { terjadi didalam game }\end{array}$ & OK \\
\hline Tombol lompati & $\begin{array}{l}\text { Ketika di Klik mempercepat } \\
\text { percakapan }\end{array}$ & OK \\
\hline Tombol Otomatis & $\begin{array}{l}\text { Ketika di klik percakapan } \\
\text { bergerak secara otomatis }\end{array}$ & OK \\
\hline Tombol simpan & $\begin{array}{l}\text { Ketika di klik masuk ke } \\
\text { menu simpan }\end{array}$ & OK \\
\hline Tombol simpan cepat & $\begin{array}{l}\text { Ketika di klik simpan cepat } \\
\text { data game }\end{array}$ & $\begin{array}{l}\text { Ketika di klik muat cepat } \\
\text { data game dari simpan cepat }\end{array}$ \\
\hline
\end{tabular}

Dari uji coba di atas dapat disimpulkan bahwa tombol di dalam game dan sistem di dalam game telah berfungsi dengan baik.

\section{KESIMPULAN}

Berdasarkan uraian permasalahan dan pembahasan pada bab sebelumnya tentang hasil penelitian pada aplikasi diagnosa depresi dengan metode beck depression inventory dengan pendekatan game visual novel adalah dengan Game Visual Novel ini pengguna bisa mengetahui apakah memiliki depresi atau tidak. Berdasarkan uji coba yang dilakukan dalam Game Visual novel ini telah berjalan dengan baik sebagaimana mestinya. Game ini hanya bisa dimainkan menggunakan perangkat computer.

\section{REFERENSI}

[1] Pieter, Herri Zan \& Lubis, Namora L. Pengantar Psikologi Dalam Keperawatan. Jakarta: Kencana, 2012.

[2] Kesehatan, Kementrian. InfoDatin Kesehatan Jiwa Situasi Kesehatan Jiwa Di Indonesia.: Kementrian Kesehatan, 2019. 
Procedia of Engineering and Life Science Vol. 2. No. 1 October 2021

Seminar Nasional \& Call Paper Fakultas Sains dan Teknologi (SENASAINS 3rd)

Universitas Muhammadiyah Sidoarjo

[3] Davison, Gerald C.; Naele, John M.; Kring, Ann M., Psikologi Abnormal. Jakarta: RajaGrafindo Persada, 2006.

[4] Renpy, What is Ren'py?, 2021.

[5] Hikam, Arif Rahman Pengembangan Game Edukasi Visual Novel Berbasis Pembangunan Karakter Pada Materi Pelestarian Lingkungan. Semarang: Universitas Negeri Semarang, 2013.

[6] Darmawan, R.S., \& Suwastono, A. MODEL SISTEM ANTRIAN. BERBASIS ARDUINO UNO R3 DAN RASPBERRY PI MENGGUNAKAN PYTHON. Yogyakarta: Universitas Gajah Mada, 2015.

[7] A.S., Rosa \& Salahuddin, M. Rekayasa Perangkat Lunak Terstruktur dan Berorientasi Objek. Bandung: Informatika, 2015.

[8] Munir, Multimedia Konsep \& Aplikasi dalam pendidikan. Bandung: CV. Alfabeta, 2015.

[9] Kuryanti, Sandra J. Perancangan Animasi Interaktif Tata Cara Pelaksanaan Wudhu dan Sholat Wajib. Bogor: AMIK BSI, 2015.

[10] Dalle, Juhriyansyah; Mutallib, A.A.; Shaari, Nassiriah; Salam, Sobihatun N.A. Pengantar Interaksi ManusiaKomputer. depok: PT RajaGrafindo Persada, 2019.

[11] Lastiansah, Sena. Pengertian User Interface.: PT. Elex Media Komputindo, 2012. 